Euskal ikerketen aldizkaria | Revue d'études basques |

Revista de estudios vascos | Basque studies review

$13 \mid 2009$

Numéro XIII

\title{
Hizkuntza-aldakortasunari Amiküzetik so
}

\section{Iñaki Camino}

\section{OpenEdition}

Journals

Édition électronique

URL : http://journals.openedition.org/lapurdum/1979

DOI : 10.4000/lapurdum.1979

ISSN : 1965-0655

Éditeur

IKER

Édition imprimée

Date de publication : 1 février 2009

Pagination : 61-80

ISBN : 978-2-86781-409-X

ISSN : $1273-3830$

\section{Référence électronique}

Iñaki Camino, « Hizkuntza-aldakortasunari Amiküzetik so », Lapurdum [Linean], 13| 2009, Sarean emana----an 15 avril 2013, kontsultatu 01 mai 2019. URL : http://journals.openedition.org/ lapurdum/1979; DOI : 10.4000/lapurdum.1979 


\title{
Hizkuntza-aldakortasunari Amiküzetik so'
}

\author{
Iñaki CAMINO \\ UPV/EHU, "Julio Urkixo” Mintegi-Institutua
}

\section{Laburpena:}

Saio honetan hizkuntzaren aldakortasuna hartuko dugu mintzagai; lehen ataletan aldakortasunaz eta soziolinguistikaren begiradaz oinarrizko ikuspegi teoriko bat aurkeztuko dugu; hiztuna eta honen kontzientzia linguistikoa ere gogoan izanen ditugu. Ondotik Nafarroa Behereko ekialdeko euskararen aldakortasunari helduko diogu, Amiküzeko edo Donapaleuko kantonamendukoari; eskualde hau Zuberoako dialekto-mugaren ondoan da, baina mugaren inguruko hiztunen mintzoan ageri diren fluktuazioei arretaz so egin behar zaie. Adibide gehienak egungo ahozko mintzotik dakartzagu.

\section{Abstract:}

The goal of this work is to talk about the variability of the language. In the first chapters we will present a basic theoretical about variability and the sociolinguistic point of view. We will take into account the speaker and his or her linguistic conscious. Later we will talk about the variability of the Basque in the East part of the Low Navarre, in the cantonment of Amiküze and Donapaleu. This district is next to the dialect of Zuberoa, and we should pay attention to the fluctuations that appear in the speakers of the border areas. Most of the examples we take them from the nowadays speakers.

Key words: Variability / linguistic continuum / bidialectal speaker / Basque of Low Navarre / dialect of Zuberoa

Gako hitzak: Aldakortasuna / hizkuntza continuum-a / hiztun bidialektala / Nafarroa Behereko mintzoa / Zuberoako mintzoa

\section{Sarrera}

Saio llabur honetan hizkuntzaren baitako aldakortasuna hartuko dugu mintzagai; laneko lehen ataletan oinarrizko ikuspegi teoriko zenbait aurkeztuko dugu aldakortasunaz eta soziolinguistikaren begiradaz ere erakutsiko dira hari-mutur batzuk; aurkezpen teoriko honetan gogoan izanen

1. Artikulu hau Nafarroako Gobernuko Euskarabidea erakundearen 440002442004800334100 (2008) eta Ministerio de Educación y Ciencia-ren FFI2008-01844 ikerketa egitasmoen barrenean gauzatu da. 
dugu hiztuna eta honen kontzientzia linguistikoa. Ondotik, datu eta adibideetara iragatean, irakurleak berehala hautemanen du dialektologiaren baitako aldakortasuna aztertzera joko dugula.

Funtsean, Nafarroa Behereko ekialdeko euskarari helduko diogu, Amiküze eskualdeko eta Donapaleuko kantonamenduko mintzoari; eskualde honetarik eskuin dialekto-muga nabarmena dago Zuberoan, baina muga horren inguruko herrietako hiztunen euskaran ageri diren fluktuazioei arretaz so egitea gauza beharra da hizkuntza-aldakortasun geografikoa xehetasunez ezagutuko badugu. Adibide gehienak ahozko mintzotik dakartzagu, egungo euskaratik, baina ez ditugu ahantzi beste hizkuntzalari batzuek bildu lekukotasunak, ezta XVIII. mendeko eta beste garai batzuetako idazki zaharrak ere.

\section{Hizkuntza-aldakortasunaren adigaia}

Eragile foniko eta morfosintaktikoek, bilakabide historikoek, gizarte-bilakabideek, belaunaldien arteko aldaketek, hizkuntza arrotzetako maileguen eraginak, hizkuntza-aldaera prestigiodunek, ondoko dialektoek, sistema estandarrarekiko adbergentzia-erlazioak, izenpetu ez baina liburuan edo idazkian sudurra sartu duen bigarren esku batek... eragile hauek guztiek hizkuntzan aldakortasuna sortzen dute, eragina beti maila eta hurrenkera edo hierarkia berean gertatzen ez baldin bada ere.

Tradizionalismoan eta historizismoan kokaturik zegoen dialektologiaz haratago joateko halako militantzia garatu zuen dialektologia sozial eta urbanoak. Uriel Weinreich-ek, 1954ko bere artikulu programatikoan dialektologia sozialaren etorkizuna aipatu zuen eta hamalau urteren buruan, saio guztiz interesgarria argitaratu zuten ikertzaile honek berak, William Labov-ek eta Marvin Irving Herzog-ek; hizkuntzaren baitako aldakortasuna hizkuntzalaritzaren saihetsetik erdigunera ekarri zuten 1968an eta horren ondorioz, salbuespentzat hartua izatetik arautzat hartua izatera iragan zen aldakortasuna.

Aldakortasuna norbanakoaren hizkuntza-gaitasunaren atal osagarria da: idiolekto indibidual homogeneoaren iruditik, hizkuntza-transferentziaren mekanismo ulergarriagora jo behar du hizkuntzalariak bere lanean; bi-idiolektalismoaren ezaugarri sinkronikoak proposatzeko behar gorria du. Esaterako, herri berean bi edo hiru forma entzun izan ditugu: Pagolan, gizon bati, eitasüna, goatasüna eta xehetarsunak entzun diogu eta haren emazteak, berriz, eitarzüna ahoskatu $\mathrm{du}$, senarraren eta gure aitzinean; senar-emazteak sortzez pagolarrak dira eta herri honexetan bizi dira. Senarrak dioskunez, Pagolan gaia eta gaua, bi aldaerak esatea gauza arrunta bide da.

Idiolekto batek darabiltzan ezaugarrien azterketa deskriptiboan, elkarren ondoan ala elkargainka dauden sistemak ageri zaizkigu. Hizkuntza-bilakabide edo hizkuntza-aldaera baten transferentzia, hiztun / mintzo / dialekto / sistema batetik beste batera gertatzen da: dialektoak etengabe elkarri eragiten ari dira (Bárczi 1963: 149). Claude Hagège-k zioen bezala, aldakortasun dialektala erregela da, homogeneotasun dialektala, berriz, salbuespena da. Dialektologialariek lehenik kritikatu duten ideietarik bat dialektoaren ikuspegi homogeneoa izan da.

Hurranen adibideak erakusten digu, Amiküze eta Zuberoako ipar-mendebala bezalako eskualde ez guztiz handi batean, aldaketak hautematen direla mintzoan, esate batera hitzen ahoskeran: ezkondu (Oragarre, Zohota), ezkondü (Martxüeta), ezkundu (Zohota), ezkundü (Martxüeta), ezkündü (Labetze), ezkonthü (Martxüeta), ezkontü (Oihergi), ezkunt eta (Zohota), ezkhüntü (Oihergi, Pagola); baita, nahi izanez gero, ezkuntza ere (Behauze, Arrüeta, Ilharre)...

Dialekto bakartuen azterketatik, elkarren ukipenean dauden dialektoen ikerketara jo zen eta honela, hizkuntzaren aldakortasuna jakintzagaiaren erdigunean kokatu. Dialektologia berri honetan, mintzoen arteko egokitzapena, ezaugarrien hedadura, dialektoen arteko nahasketa eta beste hainbat gertakari aztertzeko ereduak eraiki dira; Peter Trudgill-en 1986ko Dialects in contact libu- 
ruan gertatzen den bezala, erkidego mugikorren eredu dinamikoa ere ikerketa dialektalen erdigunera ekarri da.

Dialektologialariari etengabe ihes egiten dion aldakortasun multiforme eta ia mugagabe horrek, ordea, koherentzia sakona du kontzientzia kolektiboan, iltzaturik dago kolektibitate batek bizi izan duen historian; alde horretatik, soziolinguistikaren ikuspegi zabalak dialektologialariaren gaitasuna gainditzen du eta dialektologiaren irispidea haratago darama; izan ere, sorreraz geroztik lau dimentsioduna izan da dialektologiaren helburua: espaziala, historikoa, soziala eta kulturala. Dialektologia, gainera, jakintzagai anitzen artean kokaturik dago; Jean-Claude Bouvier-en ustez (1998: 780-781), dialektologialariak dira egungo mundu garaikideko hizkuntza-heterogeneotasuna serioski ikertzeko trebetasuna dutenak.

\section{Hizkuntza-aldaketa}

Oro har, hizkuntzak zerengatik aldatzen diren jakin nahiko genuke eta baita, bestalde, aldaketak nola eta zein baldintzatan gertatzen diren ere. Harald Haarmann-ek dioen bezala (1977), hizkuntzako sistemen eta azpisistemen arteko solidaritatearen hatsarrea ez da amets bat baizik; hizkuntzaren engranajearen edo mekanismoaren guztizko perfekziorik ezak, aldaketen bidea zabalik uzten du, zirrikituz beterik; ikus Isebaert (1977: 180).

Hizkuntzaren barrenean tira-birak eta tentsioak gertatzen dira: fonologiaren, morfosintaxiaren, lexikoaren eta semantikaren baitan egiten diren bereizketetan, osagaitik osagaira gertatu behar duten egokitzapenak ez dira beti asetzen, hizkuntza-joera berri batek osagai linguistikoen arteko konexio berriak eragiten ditu eta ordura arteko beste batzuetan etenak gertatzen dira; eragileen interdependentziak aldatzen dira eta hizkuntza-aldaketa gertatzen da; ikus Sčur (1967: 10) eta Paddock (1988: 377-378). Dena den, elkarren ondoko eremuetan bizi diren gizakiek premiazko duten komunikazioak eragiten du hizkuntza-aldaketa bortitz eta bat-batekorik belaunaldi hurbilen artean ez gertatzea.

Hizkuntzaren egituraren barrenean osagaiak ditugu eta hauek erlazioa dute elkarrekin; hizkuntza den egitura horren barrenean, erlazioez gainera sistemak daude eta sisteman, konexioa duten osagaiak ditugu, elkarri eragiten diotenak: osagai bataren aldaketak, konektaturik duen beste osagai horretan ere aldaketa eragiten du; erlazioen kasuan ez: erlazioa duten osagai guztiak ez daude beren artean zuzenean konektaturik. Hizkuntzan ez dago osagairik besteekin konektaturik ez dagoenik, baina horrek ez du esan nahi osagai bat hizkuntzako gainerako osagai guztiekin konektaturik dagoenik, beste guztiek osagai honi eragiten diotenik edo honen izaera eta aldaketak determinatzen dituztenik. Hori bai, sistemak hizkuntza den egiturari eragiten dio, presioa eragiten dio eta baita egiturak sistemari ere (Sčur1967: 15-17).

XIX. mendeko neogramatikoen arabera hizkuntza-aldaketak hizkuntzaren barrenean gertatzen dira, mekanikoki, erregelak itsuki aplikaturik; aldiz, hizkuntza-atlasen garaian aski garbi gelditu zen hizkuntza-aldaketa ugari hizkuntzaz kanpoko arrazoiek eraginak direla: ez hizkuntza ez delako sistema hertsia, hertsitasun hori guztizkoa ez delako baizik, sistema horrek dituen osagaien artean zirrikituak eta inoiz are zuloak ere ageri direlako.

Giza-gogoan hizkuntza-aldaketa nola gertatzen den jakiteko ohiko azalpenak ematen dizkigu hizkuntzalaritzak: batzuetan aldaketak mekanikoak edo automatikoak dira, ahoskera errazteak edo erosoago egiteak eraginik: asimilazioak, disimilazioak, ahostuntzeak, ahoskabetzeak, metatesiak, epentesia... Beste batzuetan paradigma morfologiko zenbaitek eragin du aldaketa mimetikoa, berdintasun bat edo logika bat bilatu nahiak, eredu baten arabera jokatu izanak: adizki, hitz edo izenordain berriak sor daitezke. Hiztunak formaren eta edukiaren artean halako lotura aurkitzen 
duenean, aldaketa lexikoak edo semantikoak gerta daitezke: herri etimologia hitz bakoitzari adiera jakin bat atxiki nahi zaionean; hitzen gurutzaketa edo kutsadura, bi adierazle iduriren gurutzaketak hirugarren adierazle bat eragiten baldin badu...

Hizkuntza-bilakabideak edo aldaketak ez dira etengabeko errepikaldiaren bidez dialekto edo mintzo guztietan era berean gertatzen; elkarren ondoko bi mintzotan, ahaidetasun hertsia duten bi mintzotan, harreman handiko bi mintzotan, ez da hizkuntza-bilakabideetan guztizko berdintasunik gertatzen, beti bada ezaugarri bat edo beste, mintzo batetik bestera, herri batetik bestera desberdina dena edo era desberdinean aldatzen edo berritzen dena.

Dialektoen arteko eragina gertatzen denean, hartu-eman dialektalaren gunean hiztuna dago; dialekto bateko hiztun batek, beste dialekto bateko hiztun baten mintzoko zenbait ezaugarri ezagutzen ditu eta emeki-emeki horiexek baliatzen hasiko da, harreman dialektala gauzatuko da eta dialekto batetik bestera hitz batzuk, hots zenbait edo morfema zenbait iragaten hasiko dira; honetarako baitezpadakoa da hiztun kopiatzaileak aldaera berriak bere erkidegoaren barrenean baliatzea, bere dialektoa mintzo dutenen aitzinean erabiltzea, dialekto honetara iragaten hasi den aldaera berri hori bertako hiztunen artean hedatzea.

Maileguaren errealitatea aztertzean, hizkuntza-aldaketak gertatzean, hiztun indibidualaren izaera psikologikoa eta soziala aintzat hartu beharreko ezaugarriak dira. Aldaketa gertatzeko ez da gauza beharra hiztun batek bi dialektoak ongi ezagutzea, aski da berea ongi ematea eta beste dialektoaz zerbait jakitea (Zawadowsky 1961: 293).

Erkidego batetik bestera iragazten diren hizkuntza-ezaugarrien kasuan, ondokotasun geografikoaren hatsarrea aipatu ohi da, baina prestigioa ere ezin ahantzizko eragilea da; bestalde, hizkuntzazko eta hizkuntzaz kanpoko arrazoiak tarteko direla, litekeena da ezaugarri berri edo kopiatua eremu urrunetako jendeenganaino iristea.

\section{Soziolinguistikaren ikuspegia}

Badakigu gizarte-egiturak hizkuntza-jokabidean eragina duela, hiztunaren hizkuntza-jokabide jakin batek gizarte-egitura jakin bat isla dezakeela eta badakigu bestalde, litekeena dela hizkuntzaren erabilera eta hizkuntza-jokabidea gizarte-egiturarekin eta gizarte-jokabidearekin osoki loturik egotea. Halaz guztiz ere, gizartearen jarduera eta hizkuntzaren funtzionamendua arras desberdinak dira.

Dialektologia egitean ikuspegi eta datu soziologikoak baliatu izana ez da beti eguneroko ogia izan, baina izan dira ikuspegiok beren lanetan baliatu dituzten ikertzaileak ere; garai batean ikertzaile frankok ezinbestekoa ikusi zuten, dialektoak ikertzean gizarteko osagai batzuek mintzoan eduki dezaketen eragina ere aztertzea. Gizarte-zientzia den aldetik aztertu nahi zen hizkuntzaren erabilera: gizartearen gune-guneko ezaugarria da hizkuntza, bereziki gizakiena den gizartea sortzeko eta iraunarazteko funtsezko tresna da. Hizkuntza den baliabide hau etengabe birsortzen ari da, ez da eraikin bukatua.

Gizarte-aldakortasuna aztertzeari eman zitzaion garrantzia, gizarte jakin bateko biztanleria osatzen duten maila ugarietan dauden hizkuntza-kodeen konbinazioa aztertzera jo zen, herrixken, eskualdeen ala eremu zabalagoen arabera: zaharrak eta gazteak, gizonak eta emaztekiak, hirietako biztanleak eta herri txikietakoak, bertan sortu jendeak eta inmigranteak aztertu nahi ziren hizkuntzaren aldetik (Bouvier 1998: 780).

Labov 1963 urtean New York hiriko saltoki handietako "r" fonemaren gizarte-mailaketaren azterketaren emaitzak ikertzen ari zelarik, dialektologia sozial kuantitatiboa asmatzen edo eraikitzen ari zen (Kac 1996: xvi), soziolinguistika esan ohi dena, baina paradigma aldaketa ez zen egun 
batetik bestera gertatu; ez genuke Harvard-eko John L. Fischer-en 1958ko "Social influences on the choice of a linguistic variant" saioa ahantzi behar.

Dialektologia eta soziolinguistika erro-errotik bereiztea jardun zaila da zinez eta honelako lanbideetan dabilenak, dialektologiaren esparrutik soziolinguistikarenera oharkabean jauzika dabilen irudipena izaten du usu: José Pedro Rona-k dioen bezala, egiazki, aldakortasun idiolektala ez da geografikoa soilik eta aldakortasun geografikoa ez da maila soziolinguistiko guztietan berdin gertatzen (1976: 11).

Soziolinguistikaren ibilbidean usu erabili diren hainbat irizpideren berri zekarren Yakov Malkiel-ek duela mende laurden bat (1984: 50):

- hizkuntza-egoera jakin bati begiratzean, gizarte-osagaia aztertzen eginahal gehiago egin beharko litzateke eskualde-osagaia aztertzen baino

- mintzo baten barreneko aldakortasunaz arreta handiagoa ezarri beharko litzateke

- lekukoak hautatu behar direnean, zerrendak ez dira nekazari-abeltzainez edo langileriako kideez bakarrik bete behar

- antigoaleko tresnen edo gauzen erosleen modukoa den "jatorrizko" dialektoen bilakuntzari betertzez begiratu behar zaio

\section{Aldagaia eta aldaerak}

Tradizioko dialektologian aldakortasun librearen adigaia ez da ezezaguna, baina aldakortasun hori dialektoen arteko nahasketaren ondorioa izan daitekeela adierazi da usuegi. Aldakortasun librearen adigaia anitz baliatu izan da hirietako mintzoak aztertu dituzten lanetan. Ezaguna denez, hirietan erkidego konplexuagoak ageri zaizkigu herri txikietan baino: erkidego konplexuetan pertsonek askotariko hartu-emanak dituzte, rol desberdin gehiagori aurre egin behar diote eta ondorioz, hirietan aldakortasun lektal handiagoa ageri da. Tradizioko dialektologian honelako aferak "polimorfismo" izenaren bidez aipatu edo moldatu izan dira.

Dialektologiaren arrakasta hizkuntzaren aldaerak aurkitu, deskribatu eta sailkatzetik etorri baldin bada, soziolinguistikak aldakortasuna aurkitu du. Aldakortasun libre horretaz mintzo garenean, hizkuntza-ezaugarri batek gauzatze bat baino gehiago eduki dezakeela adierazten ari gara, baina egoera bakoitzean zein gauzatze agertuko duen aldez aurretik ziur jakitea ia gauza ezina izaten da: hizkuntzako osagaien aldakortasun hori hizkuntza-aldaketa jakin batekin loturik egon daiteke, hizkuntza-eragile batek baldintzaturik, edo gizarte-eragile baten ingurumarian ager daiteke, ez du baitezpada aldakortasun geografikoa izan behar.

Tradizioko dialektologiak baliatzen zituen inkesten sisteman, egiten zitzaion galdera bakoitzeko lekukoak erantzun bakarra ematen zuen, baina honela ezin hauteman dira hiztunaren beraren baitan gertatu ohi diren aldakuntzak, mintzo baten barrenean ageri den aldakortasuna; ohituraz "aldakortasun librea" edo free variation esan izan zaio lekukoaren jokabide ez zurrun horri. Hiridialektologiak erakutsi du aldakortasun hori beti ez dela librea, usu gizarteko eragile batzuek edo hizkuntzako eragileek eragina izaten dela. "Hizkuntza-aldagai"-aren edo linguistic variablearen adigaia dugu hau: hizkuntza-unitate bat da aldagaia, bi aldaera edo gehiago dituena, non aldaera bakoitzak bere balio edo ñabardura sinboliko, estilistiko, kontestual edo gramatikala ukan baitezake.

Hizkuntzalaritza sortzaileak "hautazko arauak" deitzen dituenak soziolinguistikako aldagai edo variable-ak dira, aldagai bakoitzak bere aldaerak dituelarik, baina soziolinguistikak aldaera bakoitzaren agerraldien maiztasunaren neurbidea ekarri du. Labov-ekin hizkuntzaren baitako 
aldakortasuna hizkuntzalaritzaren periferiatik erdigune-erdigunera iragan zen eta erakutsi zuen, erregulartasuna eta egitura ez daudela heterogeneotasunarekin etsaiturik. Jakintzagai honen bitartez, aldakortasunaren adigaia pertsonen arteko hizkuntza-harremanen alorrera eta pertsonaren beraren baitako erabileren azterketara iragan zen.

\section{Hiztunaren proiekzioa, gizarte-sareak eta hizkuntza-merkatua}

Mintzatze-ekintza oro berez entzuleari edo entzuleei bideraturik dagoen nortasun edo identitate-ekintza bat delako tesia defendatzen du Robert B. Le Page-k (1980: 13): autoerrepresentazio bat egiten dugu mintzatzen garenean; ohartuki ala oharkabean, halako gizataldetako partaide garela erakusten du gure mintzoak. Le Page-k "proiektatzea" eta "enfokea" izendatzen dituen jardueretan engaiatu ohi da hiztuna.

Aldi berean, komunikazio eta elkar-ulermen arrazoiengatik, mintzalaguna aintzat hartzera beharturik gaude, une bateko pidgin bat balitz bezalakoa bilakatzen da bi hiztunen arteko mintzatze-ekintza, hiztunen arteko elkarreragintzaren ondorioa da, ez da zentzu chomskiarreko norbanakoaren gaitasunaren emaitza bakarrik. Hizkuntza komunikatzeko da, hiztunak aitzinean duen mintzalagunari egokitzen asmatu behar du.

Soziolinguistikako azterketek erakutsi dute hizkuntzaren erabilerari dagokionez norberaren edo hiztunaren estatusaren autokontzientzia garrantzi handikoa dela (Kroch 1986 [1976]: 345). Hiztunak bere kokagunea du gizartean eta bere nortasunaz ere badu iritzi bat; gizartean gaindi higitzeko duen itxaropenak eta kide den taldeko jendeekiko sentitzen duen elkartasunak definitzen dute pertsona baten kapital sozial, kultural eta linguistikoa; hiru kapital mota horiek elkartrukeko merkatu-egoera aldakor eta ugarietan baliatu beharko ditu hiztunak, jokoan dauden "ondasun edo sarien" arabera (Villena 1990: 168).

Hiztunak sortzen dituen esanak eta adigaiak gizarteko agertokian proiektatzen ditu. Mintzoerkidegoaren arabera gizarte elebakar bateko estereotipoekin eta adigaiekin bere burua aise identifikatzen duen hiztun batek, "enfoke" maila handiko hizkuntza-sistema duke. Esaterako, elebakarra izan gabe ere, bizi guztia Goizuetako mendiko auzo bateko baserritik ia deusetarako atera gabe eta hedabideekin hartu-eman handirik gabe bizi izan den emazteki adineko batek, mintzo guztiz enfokatua izanen du, ez du bertako mintzoa baizik eginen.

Aldiz, Baxenabarreko eta Zuberoako mugaren inguruko herrixketan bizi den euskaldunak, bere mintzoa proiektatzean ez du enfoke bakarra aski izanen, eguneroko bizian usu gertatzen delako muga linguistikoaz alderdi bateko eta besteko hiztunekin; aldakortasun-maila gora egon daiteke honelako herri batean. Esaterako, Oihergiko hiztun batek zioskunez, berek hitz baxtartak [dituzte] üskaan, manex eta xübeatar nahaska diaü. Bestalde, aitetamak biak oihergiarrak dituen lekuko bat aurkitzea ez da aise Oihergi herrian, aita edo ama ondoko herrietakoa dute gehienek: Ainharbeko, Urdiñarbeko, Lohitzüneko...; berebat, ezkontidea Amiküze aldekoa izan dezakete honelako zuberotar anitzek. Halako egoeran Oihergiko bereko mintzoari dagozkion ezaugarriak zein diren jakitea ez da aise hizkuntzalariarentzat.

Beste hiztun oihergiar batek ere halaxe aipatu zigun bere mintzoaz: ezta xübeatarra tout à fait eta ezta hankua [Amiküzekoa edo Baxenabarrekoa], biak nahastekatzen tüt nik; geo, berriz, egonik niz mithil Gersen eta han Biarno zen... biarne a Gerseko lengoa a, hua elhekatü üt, ikhasi ta geo, berriz... Ez da guztizko ziurtasun dialektala edo linguistikoa honelako hiztun batek duena, xibeutar phürra ondoko herrian baitakusa: heen ya Añharbe Xübea da de a, habooxago gü beno, Xubea atxiitzen düte han e Añarben; Añharbek Xubeala thiatzen dü. Aldiz, hiztun honi Pagola aipatu orduko, bere burua zubereraren barrenean hautematen du eta Pagola herria kanpoan dakusa: Phagola e haata amiñi at, 
heen Xubea ta han manexa ${ }^{2}$... Alta, hiztunak maite dituen kategorizazioen gainetik, hizkuntza-ezaugarrien konbinazio dinamiko eta konplexuen berri ematea da hizkuntzalariaren eginkizuna.

Zuberoako eta Baxenabarreko muga-mugako herria den Pagolan mintzo nahasia ageri da: hiztun bat gai da Xiberuko aldera nahiz manex aldera mintzatzeko, bere egunerokotasunak horretara bultzatu duelako, eta ez dugu pentsatu behar muga herrietan mintzo bata eta bestea ezaugarri guzti-guztietan matematikoki ongi bereizirik eta finkaturik ageri direnik; aldizka interdialect deitu ohi diren aldaerak ere ager daitezke, joera edo ohitura lektal bataren eta bestearen arteko nahasketak eraginak; izan ere, Pagolako herria, errekaz alde batera ala bestera gauden, erdiz Zuberoa eta erdiz Baxenabarreko Oztibarre da, administrazioz Donapaleuko kantonamenduari atxikia; historikoki Pagolako etxe anitz garai batean Oztibarreko Iutsi herrikoak ziren eta egungo Pagolara baxenabartar anitz ezkondu da. Gaude pagolarrek ez ote duten Xiberua Oxkaxez bestaldera sentitzen. Herri honetan, gainera, ez da aise bi gurasoak pagolarrak zituen edo dituen hiztunik aurkitzea. Pagola ez da Ondarroa, Zaldibia, Goldaratz edo Urdiñarbe bezalakoa, guztiz bestelakoa da bertan ageri den hizkuntza-errealitatea.

Egitura etniko eta sozialen arabera, hainbat eremutan hizkuntza-sistema "diffuse"-ak aurki ditzakegu (Le Page 1980: 16). Delako gizarte "diffuse" horietan aldakortasun-maila eta heterogeneotasuna gorak dira. Hiri handietako mintzoa datorkio nornahiri gogora honelako erkidego "diffuse"-ak aipatzean, eta bereziki trantsizioguneetako mintzoak: etnia, kultura eta hizkuntza anitz batera biltzen dituzten eremu txikiak, hainbat tributako jendeen migrazioa bildu duten Afrikako hiri berriak, Brasilgo urbanizazio garapen basatiak, mundu eslaviarreko zenbait eremu urbanoren hazkunde gaitza...

Mintzo-erkidegoa alderdi soziolinguistikotik aztertu duten lanen arabera, garrantzi handia hartu dute "gizarteko sare" (L. Milroy 1980) eta "hizkuntza-merkatu" (Sankoff \& Laberge 1978) adigaiek: lehen adigaiari dagokion ikerbidean, usu nabarmen edo begibistakotzat erakusten zaizkigun mailakatze sozioekonomikorako irizpideak zalantzan jartzen dira hizkuntzalaritzan baliatzerakoan. Ikuspegi honetan aldakortasun soziolinguistikoa ez da gizarteko mailaren arabera edo estratuka interpretatzen, jardun komunikatiboko taldeen arabera baizik.

Hipotesi gisa, lekuan lekuko mintzoaren arauekiko lotura edo atxikimendua, bertako erkidegoko sareetan norbanakoak duen integrazio-mailarekin hertsi loturik dagoela aldarrikatzen da; honela, norbanakoak gizartean duen sare-egituratzeak baluke zerikusi zuzena hiztun horren beraren hizkuntza-jokabidearekin (Milroy \& Margrain 1980: 44). Hartara, local satisfaction delakoaren maila handia duen kide bat, familia, lana eta adiskideak gune berean dituen bat, bere ingurameneko taldean ongi integraturik legoke teorian, eta leku horretako bereko mintzoaren erabilera-maila ere handia luke; hiztun honen mintzoa guztiz enfokatua litzateke.

Gizakiaren hizkuntza-jokabidea aztertu denean usu ikusi da, pertsona anitzek gatazka bizi dutela sortzezko beren gizataldearekiko duten pertenentziaren eta beste gizatalde baten erreferentziaren artean: beren gizataldearenak ez diren mintzamoldeekiko mimesi estilistikoa ager daiteke hiztun horien mintzoan, gizarteko eragileen indarra eta isla suma daiteke beren mintzatzeko moldean. Aldiz, beren taldeko kide izatea gehien baloratzen duten hiztunak izan ohi dira beste talde batzuen mintzoarekiko desberdintasunaren berri emateko zaletasunik gehien dutenak (Zamora 1986: 319).

2. Zuberoaz kanpoko euskalduna da manexa, baxenabartarra gehienetan: amiküztarrak, oztibartarrak, garaztarrak. 
Hiztunaren proiekzioaren, gizarte-sareen eta hizkuntza-merkatuaren ikerbide edo lan-ildoetan eginahal finkoa dago hizkuntza-aldakortasunaren azterketaren alderdi soziolinguistikoak oinarri teoriko egokiagoen bidez atzemateko. Gizarte-sareak aztertzean, hauen trinkotasuna eta ugaritasuna neurtzen da: zenbat pertsonak osatzen dituzten sareok, sarekideak elkartzen dituzten loturen indarra zenbaterainokoa den... Pertsona baten gizarteko sarea aztertzeko aipatu sarearen izaera (trinkoa / bakana), motak (irekia / hertsia) eta egitura (anitza / bakuna) hartu ohi dira gogoan.

Hizkuntza-merkatuaren ideiaren pean hatsarre marxista bat dago, historia eta gizartea era kritiko eta dinamikotik ikusi nahia: truke-merkatu zurrun, formal eta asimetriko horietara dagoen hizkuntzazko sarbidea aztertzen da adigai honen bidez. Merkatu adigai hau Pierre-Félix Bourdieu \& Luc Boltanski-ren "Le fétichisme de la langue" (1975) lanetik hartua da.

Merkatuak norbanakoen ekintza sozio-ekonomikoen ondorio diren jarrerak islatzen ditu; aipatu jarduerez gainera, hiztunak mintzo legitimatuan mintzatzeko gaitasunak garrantzia du: mintzo estandarra ematea, elitearena ezagutzea eta baliatzeko gai izatea, heziketa egokiari dagokion mintzamolde hori menperatzea... David Sankoff-ek eta Suzanne Laberge-k diotenez (1978: 240), hizkuntza-jarduna eta beraren aldaketak, hiztunek produkziobideekin dituzten erlazioek eraginik daude. Sexu femeninoaren barrenean, Trudgill-ek ikusi du etxetik kanpo lan egiten ez duten etxekoandreak ez direla etxetik kanpo lan egiten duten emaztekiak bezala mintzatzen (Linn 1983: 240).

Aipatu bi korronteotan, gizarte-sarearenean eta hizkuntza-merkatuarenean, egiturazkoak diren alderdi makrosozialak — estatusa — eta mikrosozialak — lekuko prestigioa, elkartasuna — aztertzen dira. Gizarte-sareen ikerketan, talde informalei garrantzi handia ematen zaie: kohesio-arauak, lekuan lekuko sare trabatuak, elkartasuna, erkidegoarekiko leialtasuna... Bi ikerbide hauek guztiz atxikitzen zaizkio Le Page-ren "Erreferentzia Taldearen Teoria"-ren ildoari. Honelako ikerketetan usu ikusi da, kide diren gizataldeko partaidetzari eta gogoko dituzten kanpoko beste erreferentziei pertsonek ematen dieten balioaren arabera - mintzatzean egin daitekeen mimesi estilistikoa barne-, hiztunen baitan gatazkak eta sentimendu kontrajarriak ager daitezkeela.

\section{Aldakortasunaren adibideak dialektologian}

Dialektologian ari denak edo testu zaharrak eskuartean hartzen dituenak, aldakortasunaren adibideak inguruka izaten ditu usu; aldakortasuna datuetan dago, baina hiztunak berak aldakortasun horren baitan murgildurik daude.

Muga dialektalaren inguruko hiztunekin jardutean, nekez lan egin liteke dialektologian biidiolektalismoaren ikuspegitik kanpo; Baxenabarre eta Xiberuko mugaren inguruko herrixketan, bederen, horrela dira gauzak. Zuberoako Olhaibin egin dugun saio batean ohartu garenez, $80 \mathrm{mi}-$ nutu dirauen elkar hizketan hiztuna herriko mintzoan ari da, baina elkar hizketaren aldi batzuetan badirudi Baxenabarreko aldaera geografikoki hedatuagoetara jotzeko ohitura edo joera duela; zernahi ere den, elkar hizketaren bukaera aldera hiztuna berriz itzultzen da itxuraz edo gure ustez Olhaibikoagoa den mintzora.

Muga lektalaren inguruko hiztun horiek badakite berenetik nahiz ondoko herrietako mintzotik ematen; hizkuntzalarien ustez dialekto desberdina den beste mintzo horretako hainbat ezaugarri entzutearen entzutez ikasi dituzte eta badakite nola esaten diren, bilakabide zenbait barreneratu dute, badakite beren sorterrikoak ez diren ezaugarri horiek hiztun kanpotar baten aitzinean edo ondoko herritarren aitzinean erabiltzen, badakite horiei begira mintzatzen. Gertakari hau frankotan errepikatzen baldin bada, bertakoa ez zen ezaugarria hondarrean bertako mintzora sartzen hasiko da, jatorrizko lehenagoko ezaugarriekin batean aldakortasun erlazioan nahaska erabiliko da behar- 
bada ezaugarri hori.

Aldakortasunaren gibelean zer dagoen, aldakortasun hau zerik gertatzen den, hainbat eta hainbat arrazoik argitzen ahal dute; denok dakigu, bestalde, zer egin daitekeen aldakortasun horretaz argitasun pixka bat erdiesteko, badira baliabideak gaiari ekiteko:

- hizkuntza-ezaugarri edo fenomeno berezi baten adibide paraleloak bilatzea

- gramatika sakontasunez aztertzea

- azterketa fonetiko eta fonologiko sakonak egitea

- lekuan lekuko datu-bilduma geografiko xeheak egitea

- testuetan ezaugarri batek duen agerraldien maiztasuna diakronikoki neurtzea (Dees 1988, 1989)...

Hurrengo lerrootan Nafarroa Behereko ekialdeko Amiküze eskualdean mintzoan sumatzen den aldakortasunaren adibide zenbait dakargu.

\subsection{Aldakortasuna datu-bildumetan}

Ipar Amiküzen, kaskoinaren muga ondoko herrixketan, $u$ bokalaren alofono palatal edo delako ü baliatzen dute hiztunek euskal hitzetan. Koldo Artolak Amiküze ibarrean ü-rik egiten ez duten herrien zerrenda eman zuen duela urte multso bat (Irizar 2002a: 22): Oragarren, Amorotzen, UharteHirin, Mithiriñan, Ostankoan eta Larribarren ez dela ageri diosku; funtsean, Amiküzeko hegoaldean falta da. Esaterako, 1913an Rudolph Trebitsch etnografoak Adolf Berdeco lekuko amoroztarrari grabatu zizkion pasarte batzuetan ez da ü honen arrastorik ere ageri (Etxebarria 1994: 65).

Alta, Oragarreren kasuan harritzeko ere bada hau: alde batetik egia da mendebalera Aiherra duela Oragarrek eta Aiherran ez dela ü egiten frantsesezko maileguetan baizik, hau da, euskal hitzetan ez da ü-rik entzuten Aiherran. Halarik ere, Oragarrek iparrean Bardoze eta ekialderat Arrüeta ditu eta bi herriok ü baliatzen dute. Arrazoi du Artolak Oragarren ü-rik ez dela dioenean: herri horretako hiztunen ahotan ia ez da entzuten eta Artolak berriemaileengandik ez zuen entzun, baina baliatzen dute ü hori inoiz oragartarrek.

Guk bildu datuen arabera, Oragarren bada ü zerbaixko; guti izanik ere, hona hiru adizkitan gertatu palatalizazioa: zün 'zuzun' (1985), aigü (1985), so izazü (2006); maileguetan, jakina, ez da harritzeko gauza ü agertzea: debalüatu (1985). Koldo Artola ikertzailearen lan bikain eta emankorra deusetarako auzitara ekarri gabe, datuok xuxen erakusten digute hizkuntzalaritzan gabiltzanon artean ere aldakortasuna gertatzen dela datuen bilduman; errealitate mintzatuan badagoen ezaugarri bat bildu den corpusean ageri ez delako ala hizkuntzalari batak eta besteak errealitate bera desberdin entzuten dutelako. Hizkuntza-atlasetan ere, ikertzaileen beren entzuteko gaitasun desberdinak aldeak eragin ohi ditu mapetara emaitzak eramatean edota entzuten dena edo entzun uste dena interpretatzerakoan. 1925eko Tableaux phonétiques des patois suisses romands lanak argi eta garbi utzi zuen inkestan zehar bi inkestatzailek hots bat eta bera desberdin entzun dezaketela.

\subsection{Aldakortasuna ü-ren baldintza fonologikoetan}

Zuberoakoak baino baldintza hertsiagoak dira euskal hitzetan ü palatalizatua agertzeko Amiküzen daudenak, ekialdeko baxenabartarrek ez dute mintzatzean xuberatarrek bezainbat ü egiten; Bonaparteren garaitik dakigu hau (1869: xiv); printzeak zioenez, ibar honetan düzü \& dün adizkiak baliatzen dira, baina duk adizkian ez da $u$ bokala palatalizatzen; ondotik Amiküzen bildu diren lekukotasunek gauzak honela direla erakutsi dute.

Belaunaldi baten ondotik XIX. mendearen bukaeran Bordeleko Unibertsitateko irakasle Edouard Bourciez-ek haur prodigoaren parabola beren sortzezko mintzairara itzultzeko agindu 
zien Bordele eskualdeko eskoletako errientei eta euskal lekukotasun ugari bildu zuen Ipar Euskal Herrian. Guk hona Bourciez-ek Amiküzeko Gamue-Zohaztiko J. Pitrau errientarengandik bildu itzulpenaren emaitzak dakartzagu lehenik, 1894 ingurukoak; palatalizaturik dauden hitzen zerrenda da (Aurrekoetxea \& Videgain, 2004: 124-126):

akordatü, alegeratü, arnegüz, baitüte, baitzintüdan, barkhatü, behaztün, bekhatü, bildü, bürian $\&$ büriari, deithü, despendiatü, dihürü, düana, dügü, düt, düten, egün, erreprotxüik, ezaazü, früta, galdatü, galdüik, gütien, güzia, hantüz, hartü, heldü, herrestatüz, itzültzen, khantatü, kitatü, lüzatü, maithatü, müthilek, nezazü, nüzü, obeitü, obendün, ontasüna, ordü, phartitü, peritüz, pünitü, saldü, süik, tüzten, ürrün, ützi, xakhürrekin, zazü, zütaik, züten.

Ikusten denez, honako inguruneetan Gamue-Zohaztin u palatalizatu da:

Hitzaren hasieran: gütien, güzia, müthilek, süik, zütaik

Hitzaren bukaeran: bekhatü, ordü, arnegüz, erreprotxüik

Hitz bukaeran koda duelarik: behaztün, egün, obendün, ontasüna, xakhürrekin

-tu aditz atzizkian: akordatü, alegeratü, barkhatü, bildü, deithü, despendiatü, galdatü, khantatü, kitatü, lüzatü, maithatü, hantüz, hartü, heldü, herrestatüz, galdüik, phartitü, peritüz, pünitü, saldü, obeitü

Adizki laguntzaileetan: düana, dügü, düt, düten, baitüte, baitzintüdan, ezaazü, nezazü, nüzü, tüzten, zazü, züten

Hitzaren erdian: itzültzen

Asimilazioetan: dihürü

Maileguetan: früta

ürr sekuentzian: ürrün

ütz sekuentzian: ützi

Honako beste zerrenda honetan Gamue-Zohaztin 1894ko datuen arabera u bokalaren palatalizatu gabeko alofonoaren adibideak dakartzagu, betiere ingurune fonikoaren arabera sailkaturik:

Zuberoan ez bezala, herskari belarraren aitzinean **ük ezintasuna ageri da: ukhan, kukutia, zukenez, bitzuken, duk; parabolan zuken vs. züten ageri da

Ttak kontsonantearen aitzinean **ür ezintasuna ageri da: zure, ur handi, gurekin

" $\mathrm{r}+$ herskari horzkaria" sekuentziaren ondotik **u $>$ ü ezintasuna ageri da: urdek, urthatzia

Txistukari igurzkari apikariaren aitzinean **üs ezintasuna ageri da: ikhusi \& ikhustea, usteldu, uste, irus, malerus...

Txistukari afrikatu apikariaren aitzinean **üts ezintasuna ageri da: hutsa3 ; hona, berriz, diptongokoa denean: errautsez

Diptongoan **aü ezintasuna ageri da: aurdikitzen, haurra, gauaz; diptongo berrietan ere ezintasuna dago: nausi, baut, naukan, gehiau, nindaun

$u$ berrietan ezintasuna ageri da: nun 'non', hun 'ona'

3. Trebitsch-ek Bardozen huts egin adibidea bildu zuen (1913), palatalizatu gabe (Etxebarria 1994: 68). 
Beste adibide batzuetan ere palatalizatu gabe ageri da: duzketzie...

Behauze herria ez dago Gamue-Zohazti bezala Amiküzeko iparrean, erdigunean dago; Trebitsch-ek Behauzen 1913an bildu emaitzetan (Etxebarria 1994), u-ren palatalizazioa ez da iparreko herrietan bezainbat gertatzen; esaterako, -tu aditz atzizkiarekin kontsolatüz eta patitüz maileguak ditugu, baina baita palatalizatu gabeko harturik, khundatuko, lothu, orhiturik edo sendatu adibideak ere. Jeanne-Marie Mendibil bardoztarrarengandik Trebitsch-ek hartu adibideetan ere, bi jokaeretarik dugu: delibatü, esposatü, gelditü, hartüik, kuntentatüko, makhürtü, paatüuk eta plazatü, batetik, baina baita palatalizatu gabeko afermatu, bildurik, ezagutu, instalatu, pasatu, sarthu edo sorthu adibideak ere.

Beste belaunaldi baten ondotik, 1936an René Lafonek beste gamuetar baten lekukotasunak bildu zituen Bordelen; honela, Bourciez-en eta Lafonen emaitzak alderatzeko aukera dago, bildumen artean 42 urte inguru ditugularik. Lafonek berrogei urteko emazteki gamuetar baten datuak dakartza eta dioenez, emazteki hark ez zuen inolako zalantzarik u eta ü-ren arteko bereizketa egitean; Mérignac-eko euskaltzaina ohartu zen emazteki gamuetarraren ahoskera eta Bourciez-en Gamue-Zohaztiko itzulpeneko erabilera bat datozela.

Gamueko emaztekiaren datuetan, $r, s$, ts, g eta k-ren aitzinean ez da ü gertatzen: huts, súge, kukúso, lukhinka, nuk, duk, sukhálde, úkhan, ukhátü...; ordea, beste ingurune foniko batzuetan ü palatala egiten zuen emaztekiak, esaterako, sü, éskü hitzetan edo nün, dün erako adizkietan. Gamueko emaztekiaren arestiko $u$ ez palatalizatu horiek guztiak zubereraz ü dira. Emazteki hark emanak dira úrzo, eskúna eta asúna adibideak ere, zubereraz ürzo, esküna eta asüna egin ohi direnak. Adibide bakarrean bereizi zituen $u$ eta ü ingurune foniko berean emazteki gamuetarrak: nün 'naun' / nun 'non' (Lafon 1962: 95-96).

Guk 1985ean eta 2005-2006 urteetan Amiküzen bildu ditugun datuak hein batean Lafonenekin bat datoz, baina ñabardurak egin daitezke; morfonologiak erakusten digu $k$ kontsonante belarra lexemaren mugatik harat dagoenean, ük sekuentzia fonikoa gertatzea ez dela ezina; Charles-Auguste Le Quien de Laneufville apezpikuak 1786an Akizeren menpeko fededun baxenabartarrentzat berrargitarazi zuen katiximan lekuco (8) eta seinduco (35) adibide palatalak ditugu eta berdin gertatzen da guk bildu honako adibideetan ere: gük, finitüko, ordüko \& ordükotz, zaküka \& zakükari (Martxüeta); ingürüko (Gamue); gük e, axerüka (Arboti); negüko (Laphizketa). Gure datuetan, lexema barreneko lehen ük geografikoa Zuberoako mugako lehen herri Lohitzünen ageri da: ükhan, zeina ondoko Oihergin eta Pagolan ükhen egiten baita; artean, Amiküzeko herrietako ukhan aldaera palatalizatu gabea $\mathrm{da}^{4}$.

Herskari belar ahostunari dagokionez, üg ez dugu bildu adibide honetan baizik: dügü (Laphizketa); ohikoa ug da, Ilharreko sugiak 'sugeak' adibidean bezala.

Dena den, Bourciez-en edo Lafonen datuetan ez bezala, gure datuetan ez dago ür sekuentziaren guztizko ezintasunik, adibide bakan batzuetan bada ür: bürian (Martxüeta); ingürü, bilküran, azürian 'azerian', ostatürat (Ilharre); bürü, ingürü (Gamue); güre \& güriak, bürü, üdüri (Arboti); bilküra, aidürü (Zohota); idüritzen (Arberatze); üdüri \& üdüriko, üngürü \& üngürian, güretako (Laphizketa).

4. Egia esan, Arberatzen bildu dugun pare bat adibidetan ez dakigu xuxen gure belarriak ukhan ala ükhan entzuten duen, ala bi errealitateen arteko continuum-aren barreneko u palatalizatuxe bat entzuten ote duen, Bonapartek Nafarroa Garaiko hainbat ibarretan entzuten zuen harako $u$ eta $\ddot{u}$ arteko hotsaren gisa. 
Aldiz, üs sekuentzia maileguetan baizik ez da ageri: batüsaekilan, üsü (Martxüeta); üsü (Labetze); üsaien, arrüsatiak (Laphizketa); üsian, üsatiak, küsialehenak (Lohitzüne).

\subsection{Aldakortasun grafikoa}

Charles-Auguste "Le Quien de Laneufville" Akizeko apezpikuak 1786an arrainprimarazi zuen kristau ikasbidean, $<o u>$ eta $<u>$ grafien jokabidea, euskal ekialdean $u$ eta ü bereizten duten mintzoetan ohiz espero litekeena da eta horretan oinarriturik, Alphonsa Rodriguez-en Lopezen itzulpenaren kasuan ez bezala, Orotariko Euskal Hiztegia-k $\langle u\rangle /<\ddot{u}\rangle$ bereizketa grafikoa baliatu du kristau ikasbide hau transkribatzeko. Hona Amiküzeko katiximatzat jotzen den liburu honetako adibide batzuk:

$<o u>$ :

$u$ hitz hasieran: gouhaurec (38), ouhaitzcian (40)

urt: ourthe (40) \& ourthetaraino (40)

uk: ouquen 'ukan' (7)

us: icous (9) \& icoussi (39) \& icousten (6)

ur: hirour (6), houra $(7,33)$

hiatusa5: gaiñecoua (6), templouan (8), ondocouac (33), mysterioüan (36), humanoüa (36) \& humanoua (36), marchouaren (37), bessouetan (39), demoniouaz (41)

bigarren mailako u: noun 'non' $(7,38,40)$, hounen 'onen' (10) \& hountarçuna (36), jouanic 'joanik' (40)

besterik: igoüalki (36)

$<u>$ :

ü hitz hasieran: Urhe 'urrea' (38), urço (49) —baina Lafonen Gamue-Zohaztiko berriemaileak úrzo zerabilen 1936an, palatalizatu gabe-, gu (9), guri (8), burian (39), lurrerat (9) \& lurra (33), curutciaren (8), gucien (8) \& guciac (33), baiçuten (33)

ü hitzaren erdian: buluciac (33), aingurien (38)

ü hitzaren bukaeran, koda izan nahiz ez izan: ceru (40) \& cerurat (9), du (8), ditu (33), guitu (8), duçu (34), dacogu (38), becatu (33), gorphutz (7), eguna (8), hartuz (36)

maileguak: mundiaren (9), jujatia (9), unitu (35), miraculu (38), Jesu-Christoren (8)

ük lexemaren mugan: seinduco (35), lekuco (8)

Halarik ere, hainbat hitz edo egitura bi eratara idatzirik ageri dira kristau ikasbidean, argitalpenak aldakortasuna ageri du:

ur: goure (8) \& goureçat $(8,34)$, gouriac (7) / gure (9), guri (8)

urt: Ourthaxez (38) / Urthax (8); Ourtharilaren (39) / Urtharrilaren (8)

uk: ouquen (7) / uqhen (37)

un: hountarçuna (36) / huntarçunac (38); houna 'hona' (34, 35) / hunec 'honek' (34)

hiatusean: ondouan $(9,33)$ / onduan (9); Gincouaren (35) / Guiristinuac (34) 
Egia esan, <urthax $>$, <urtharrilaren $>$, <huntarçunac $>,<$ hunec $>$, <onduan $>$ edo $<$ guiristinuac $>$ erako adibideek, testuko bereizketa grafiko gehienen balioa hondatzen ez badute ere, zalantza galanta eragiten dute hizkuntzalariarengan.

\subsection{Aldakortasun geolinguistikoa idazkietan islaturik}

Ipar Euskal Herriko idazleen datuak kronologiaren arabera antolatzen baldin baditugu, hizkuntza menderen mende nola aldatu den ikusi ahal izanen dugu, historia aldatzailearen emaitza begien aitzinera etorriko zaigu; hori egitean ikuspegi edo irizpide dialektologikoa baliatzen baldin badugu, Ipar Euskal Herriko mendebaletik ekialderat euskal lexikoa aldatuz doala ohartuko gara.

Lan honen hurrengo atalean Nafarroa Behereko ekialdean Amiküze ibarrean gaindi euskara emeki-emeki aldatuz doala eta Xiberukoaren gero eta eite handiagoa hartzen duela ikusiko dugu. Hori egin baino lehen, ordea, aldakortasun historikoa eta geografikoa euskal idazleen lanetan jarrai daitezkeela erakusten diguten hitz batzuk aurkeztuko ditugu ${ }^{6}$. Geografian gaindi euskaran ageri diren desberdintasunen erakusgarri dira hurranen lau eleak:

Leizarraga: laranbate / 1651 ko pregariak: euiacoitcian / Oihenart: larunbatez / Tartas: irakoizian / Belapeire, Oloroeko katixima: neskenegün / Le Quien de Laneufville apezpikuak argitarazi katixima: iracoitcez / Iribarnegarairen Baigorriko San Mateoren ebanjelioa: ebiacoitz

Etxepare: ahaidiec / 1651ko pregariak: ascasi \& ahaide / Tartas: asquaziac; asccaciak eta ahaidiac oro / Zuberoako Pronus (1676): asquaci / Maister: ascaci / Lopez: azkaci / Le Quien de Laneufville apezpikuak argitarazi katixima: askazi / Cazenavek itzuli Garaziko Jondone Juaneren apokalipsia: jendakia

Leizarraga: belar \& bekoki / Harizmendi: beccoqui / Oihenart, Belapeire, Lopez, Le Quien de Laneufville apezpikuak argitarazi katixima, Donapaleuko katixima: belar / Donamartiriko katixima: kopetan / Cazenavek itzuli Garaziko Jondone Juaneren apokalipsia: kopetetan

Etxepare, Leizarraga: iguzki / Oihenart: eki / Tartas: iguski / Belapeire, Maister, Lopez: ek(h)i / Le Quien de Laneufville apezpikuak argitarazi katixima: iguskia / Iribarnegarairen Baigorriko San Mateoren ebanjelioa: iuzkico / Salaberrik itzuli San Mateoren ebanjelioa: ekhia / Garaziko Canticum trium puerorum, Bonapartek berak itzulia: ekhia

Beste adibide honetan, ordea, eskualde batean iraun duen hitza dugu:

Leizarraga: urtharril / Oihenart: loila / Le Quien de Laneufville apezpikuak argitarazi katixima: ourtharilaren / Gèze: hourtahila

Eskualdekoa da eta dirudienez Baxenabarreko ekialdekoa bert(h)aite aldaera ere:

Etxepare: begitartia / Leizarraga, Oihenart, Maister: begitharte / Lopez: bertaithia \& beitarte / Le Quien de Laneufville apezpikuak argitarazi katixima: berthaite / Cazenaveren Garaziko San Mateo-

6. Grafia bere horretan dakargu, estandarizatu gabe, non eta ez dugun bereizkuntza fonologiko garrantzizko bat adierazi nahi.

7. Jeanne-Marie Mendibil bardoztarrak 1913an Trebitsch-i ele bera eman zion: delibatü dizit ezkontzia igaan llollan (Etxebarria 1994: 69); berebat, Euskal Herri Hizkeren Atlas-erako Xarles Videgainek Bardozen llolla bildu zuen. 
ren ebanjelioa: beithartia / Iribarnegarairen Baigorriko San Mateoren ebanjelioa: beitartiak.

Hona orain desberdintasun geolinguistikoa hamar aldaera lexikoren arabera aurkezturik:

Etxepare, Leizarraga, Axular: afari / Oihenart: auhari / Belapeire, Maister: aihari / Lopez: auharian / Cazenaveren Garaziko San Mateoren ebanjelioa: aufaria / Géze: aihari

Leizarraga: bedratzi / Oihenart: bederatzi / Tartas \& Belapeire: bederatzü / Lopez: bederatzi / Donapaleuko katixima: bedeatzi / Gèze: bederatzü

Leizarraga, Oihenart: biharamun / Tartas: biharamenian \& biharemanian / Maister: biharümen, biharümeniala / Lopez: biharamun / Cazenaveren Garaziko San Mateoren ebanjelioa: bihamun / Iribarnegarairen Baigorriko San Mateoren ebanjelioa: bihaamunak / Gèze: biharamen

Leizarraga, Materre, Etxeberri Ziburukoa, Axular: elk(h)ar / Etxepare, 1651ko pregariak, Oihenart, Tartas: elgar / Belapeire: nagusiki algar, baina bi adibide bakanetan alkhar / Maister: alkhar \& algar / Lopez, Bazkazaneko 1762ko idazkiak (Orpustan 2005), Ibarrolako Salaberriren hiztegia eta bere San Mateoren ebanjelioa, Iribarnegarairen Baigorriko San Mateoren ebanjelioa, Donibane-Garaziko katixima, Donamartiriko katixima: elgar / Gèze: alkhar \& algar

Etxeberri Ziburukoa, Axular: ergel / Leizarraga: erguelqueria / Oihenart: elgerra, elgerki; badarabil ergel ere / Tartas: elgerra / Iribarnegarairen Baigorriko San Mateoren ebanjelioa, Gèze, Barbier garaztarra: ergel

Axular, Materre, Pouvreau: eskale / Oihenart: eskale / Tartas: ezqueleric \& eskale / Lopez: eskele / Ibarrolako Salaberriren hiztegia: eskale / Etxahun, Gèze, Archu: eskele

Etxepare, Etxeberri Ziburukoa, Axular, 1651ko pregariak, Oihenart: garizuma / Tartas: garazüma \& garezüma; garizüma behin baizik ez / Belapeire: gorozüma; cf. Zuberoako goroxima \& goroxüma eta Gèzeren goroxüma \& gorozema / Bazkazane 1762: garizoma / Lopez: gariçuma / Le Quien de Laneufville apezpikuak argitarazi katixima: gariçoma eta OEH-k dakarrenez, baita gariçuma ere / Jean Pierre Arbelbide: garizoma

Etxepare, Leizarraga, Etxeberri Ziburukoa, Axular, Oihenart, Archu, Iribarnegarairen Baigorriko San Mateoren ebanjelioa, Cazenavek itzuli Garaziko San Mateoren ebanjelioa, Donamartiriko katixima: hautsi / Tartas, Belapeire, Egiategi, Gèze: hautse

Etxepare, Leizarraga, 1651ko pregariak: zeru / Tartas: zelürat \& zelüti / Pronus 1676, Belapeire, Maister: zelü / Lopez: celuco / Donapaleuko katixima: zelu gehiago, baina baita zerian ere / Donibane-Garaziko katixima: zeria / Iribarnegarairen Baigorriko San Mateoren ebanjelioa: cerutik \& zeria

Leizarraga: zutik / Oihenart: xut (adjektiboa) / Tartas, Belapeire: züti / Maister: xüti / Lopez: çuti / Cazenavek itzuli Garaziko Jondone Juaneren apokalipsia: xutik / Iribarnegarairen Baigorriko San Mateoren ebanjelioa: chutik

Aurkeztuko ditugun adizlagunotan ere ezagun du mendebaletik ekialderat aldea dagoela eta eskualdeotan hizkuntza-batasunik ez dagoela; Euskal Herriko ekialdean barne eta gain inesiboan baliatzen direnean, ezkerrean duten izena ere inesiboan jokatzen da:

Leizarraga: vr barnean / Tartas: grazian barnen; Eliçan barnen / Pronus 1676: zortzi egünetan barnen / Maister: thempora llaburretan barnen / Lopez: haren bihotzçaren barnian

Tartas: gorotzaté batetan gaigñian hedaturik çagoela; bere hoiñak elkharretan gaiñen plegatürik / Belapeire: itçatu baitcien Curutché hartan gagnen, baina badarabil genitiboarekin ere, inesiboan "batetan" espero baikenuke, non eta baten ez den inesibo zaharra: Cergatic Jesus hara sarthu cen asto baten gagnen? / Maister: çougnec jujatu behar beinai ene gaiça eguinetan gagnen; besteren eguitecouetan gagnen; inesiboa dirudi honek ere: ecetare lurren gagnen guiçonic batere / Lopez: eguietan gagnan; hetan gagnan; hortan gagnan / Le Quien de Laneufville apezpikuak argitarazi katixima: Jaunaren 
merechimendu infinitouen gaignian; ezpagnaren gagnera / Iribarnegarairen San Mateoren ebanjelioa: asto baten gainian

Aldiz, artekan 'artean' Nafarroa Behereko ekialdeko eta Zuberoako aldaera dela dirudi eta ez dugu XVIII. mendea artean aurkitzen:

Leizarraga: handic ilki arterano / Tartas: attentionia orationia accava artino / Belapeire: hausteric Bazco çaharra igaran artio / Lopez: idoc artekan; Jaunac ezkia heda artekan / Egiategi: zü hil artekan / Le Quien de Laneufville apezpikuak argitarazi katixima: ecesta artecan / Cazenavek itzuli Garaziko Jondone Juaneren apokalipsia: ni jin artekan / Donapaleuko katixima: mundia finitu artio

Zuberoako 1837 inguruko Uskara libru berria delakoan ere artekan ageri zaigu eta OEH-ren arabera, mendebalean Duvoisin da erabiltzaile lapurtar bakarra.

\subsection{Aldakortasun geolinguistikoa Amiküzen gaindi}

Amiküzeko gizartean Euskal Herriko beste eskualdeetan baino hizkuntza-aldakortasun handiagoa aurkitzeak ez gintuzke harritu-arazi beharko; izan ere, jende anitz etxetier izan baita, bizileku finkorik gabea, higikortasun handia egon da bertako biztanleen artean; jauregiaren, lurren eta egoitza batzuen jabe den etxekojaun baten alde erdizka lan egin du, haren lurretan, haren jabegoko etxe batean biziz; langile txiroak sos puska bat biltzea erdietsi orduko, bere sorterria ez den baina Amiküze ibarrekoa den beste herri batean lur sailak beste jaun bati erosi eta beharbada herri horretakoa ez den ezkontidearekin bizian eta laborantzan plantatzen edo kokatzen egin du eginahala; beste euskal alderdi batzuetan baino nahasketa handiagoa dago herritar amiküztarren artean: beste alderdi batzuetan baino, lurrak eta etxeak eskutik eskura gehiago ibili dira eskualde honetan, higikortasun geografiko handia izan da bizilagunen aldetik; iduri luke, dena den, Amiküzen gelditzeko joera egon dela, herri batetik bestera, baina Amiküze barrenean.

Goi-behe, ezker-eskuin, Amiküze ibar handia da, hizkuntzaren aldetik ez da eskualde guztiz homogeneoa: mintzoen arteko desberdintasunak, hizkuntza-ezaugarri desberdinen ugalketa, herririk herri emeki-emeki gertatuz doaz, mailaz maila; Arberoatik Zuberoarat Amiküzen gaindi continuum geolinguistiko nabarmena ageri da herririk herri joanez gero; guk ibilbide hori egin dugu, mendebaletik Amiküzen gaindi Zuberoako mugaraino inguratu gara.

Bidaia honetan bi ezaugarri mota bereizi nahi izan ditugu: //// irudiaren ezkerrean eman ditugun hizkuntza-ezaugarriak ez dira Euskal Herriko ekialdeko tasunak, Ipar Euskal Herrian eta Baxenabarren aski hedadura handian baliatzen direnak izan daitezke, baina ez dira, esaterako, Xiberukoak; aldiz, //// irudiaren eskuinera utzi ditugunak, horiek ekialdean eta Zuberoan baliatzen diren ezaugarriak dira, nahiz batzuk bederen Nafarroa Behereko hainbat eskualdetan ere erabiltzen diren; denak ez dira ekialdeko esklusiboak, baina ekialdekoak dira //// irudiaren eskuinaldera utzi ditugun ezaugarri guztiak.

Ezaugarriak sei hizkuntza-arlotan banatu ditugu, alderdi fonikoa, izenaren morfologia, aditzarena, alderdi sintaktikoa, alderdi lexikoa eta aldaera lexikoak aintzat harturik; hizkuntza-alderdi bakoitzetik bestera iragatean / irudia agertuko da gure emaitzetan.

Hartara, irakurleak honela irakurri behar ditu datuak:

I/II = joera lektalean aldaketa $\quad$ / = gramatikako atalean aldaketa

Bestalde, berrikuntzen eta arkaismoen agerpen geografikoaren irudiak edo dinamikak ez luke berdina izan behar, espero genuke arkaismoek maparen gainean uzten duten irudia eta berrikuntza hedatu indartsuek uzten dutena berdina ez izatea; esaterako, -tarzün atzizki zahar ekialdekoak edo "nx" eta "rx" sekuentziek hanxe edo horxe erako adizlagunetan ez lukete baitezpada osotasun geo- 
grafikorik eduki beharko, ager litezke ekialdeko bazterretan han eta hemen, uharteen moduan, gorputz osorik erakutsi gabe; aldiz, Euskal Herriko erdigunetik eskuinerat datozen berrikuntzek irudi osoagoa edo jarraikorragoa eduki beharko lukete; esaterako, Baxenabarren -ten aditz-atzizkia ordezkatzera jo duen -tzen aldaera berriaren hedaduraren irudiak osoagoa beharko luke, ez litzateke uharte moduan agertuko, itsasoko marearen goraldiaren antzera baizik.

Gogoan hartzekoa da, bestalde, Euskal Herriko hizkuntza-ekialdea ahul dagoela, Zuberoak, Erronkarik, Zaraitzuk edo Amiküzek gizarte aldetik ez dutela beren artean batasunik, gizartearen eta erakundeen aldetik errealitate desberdinetan murgildurik daudela, ekonomia apalduz doala eskualde horietako bazter gehienetan eta euskara bera ere, gainbehera gogorrean sarturik dagoela; gizarte-egoera hau ez da egokiena hizkuntza-berrikuntzak sor eta heda daitezen. Berebat, Amiküzen ere gainbehera doa euskara eta beraz, bertara Lapurdi-Baxenabarretik edo Euskal Herri orokorragotik irits daitezkeen berrikuntzak ez dira gizarte euskaldun guztira hedatzen, euskaraz mintzatzen jarraitzeko halako barne erabakia hartu duten hiztunengana baizik, eta hauen artean bereziki helduengana edo gazteengana, zaharrengana ez; oroitaraztekoa da guk datu biltzeko lekuko adinetakoak hobetsi ditugula, Amiküzeko berezko euskaratik nahi baikenuen.

Gure artikuluan aldakortasun geografikoaren aurkezpen orokorra egin nahi dugu, ez dugu aldakortasun horretan ezaugarri berriek eta zaharrek duten jokabidearen azterketan sakondu nahi, bego gai hau beste aldi baterako.

Beste baterako utz litezke ezaugarri bateratzaileak ere; adibide baten bidez aise ikusten da badela halako berezitasun bat eskualdeko euskaran; Zuberoan edo Nafarroa Behere gehienean ez bezala, -radio atzizkia baliatzen da Amiküzen muga adlatiboa adierazteko: noadio 'noraino' (Behauze), hanbestetaadio (Behauze, Martxüeta), hoinbestetaadio, horradio, Panplonaadio, Donapaleadio, hamoostetadio (Labetze), Hazparneadio (Arboti)... Ikusteko legoke, esaterako, -xe atzizkiaren gehiegitasun adiera Amiküze guztian nagusi den, ala ezaugarri banatzailea den: geo progria re, ai nuk amiñi at fitexe yuiten denez e 'nago aitzinamendua lasterregi ez ote doan ere' (Labetze); noraino iristen da gañan 'gainean' aldaera, bestalde? Saio llabur honetan ez diogu Amiküzeko hizkuntza-ezaugarri bateratzaileen gaiari helduko; bego beste aldi baterako.

Hona orain gure bidaian bildu dugunaren erakusgarri bat; ezaugarrien aurkezpen orokorra egiteko mendebaleko herrietarik ekialderat joko dugu:

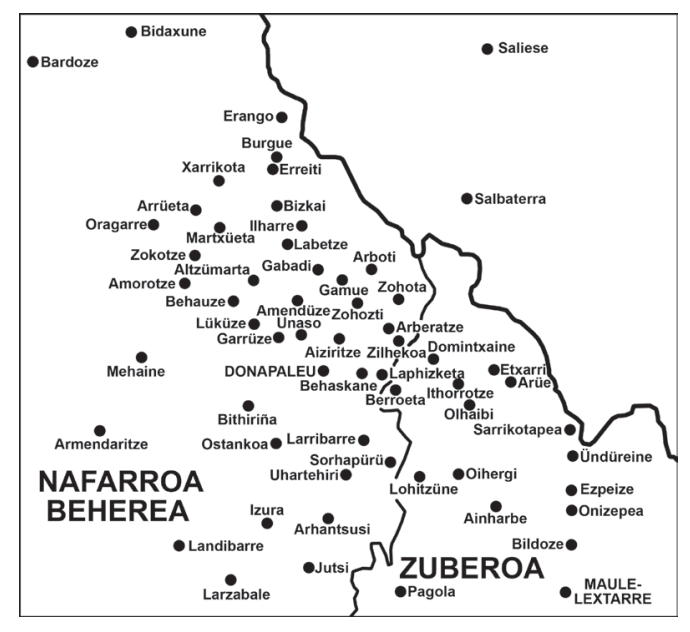


Mehaine (Arberoa): liburiak, auzo / ainbestetaano / iduzki / elgar, eritasun, hemen /II/ tresnekilan, erretretalat, etxen

Oragarre (Amiküzeko mendebala): iortzen 'igortzen', ibiltzen / bihamonian, gaztetasun /I// barruku; uñez; aigü, zün, izazü / gintxun E eztaizut; karga liote orga / ezpitakit nik lamina horiek zer zien ote I arraitzuli, eontsi 'erauntsi, jardun': dantzan eontsi gintiela

Arrüeta (Amiküzeko mendebala): zaunkutelaik 'zigutelarik' / behorrak //I/ aizoetan 'auzoetan'; ezkuntzaz 'ezkontzaz' / etxengo arthua / jalgiten, joiten, ezarten, i(b)ilten; esküz bil eta esküz karga; hartan har eta gero orgetan ezar

Behauze (Amiküzeko erdigunea): idüri / aitatxi ta amatxiak, iuzkia / ederrak, goratasuna, ontasunak /II/ soldadokan / gu bezainbeste / abooxia, azkazi, gozaita / hogeitamar

Bithiriña (Amiküzeko hegoaldea): ü-rik ez; ezarri / ahaide / elgar, eritasun, hemen /II/ huñez / etxengo (xedea) vs. etxeko (lokatiboa); mezalat E eskolala / iilten; zaukiuzun 'zigun' zuketan / aiduru, ber gauza, eontsi / heen 'heben', hogei; -gerren '-garren'

Martxüeta (Amiküzeko ipar-erdigunea): barnatasun //I/ aizo; ezkonthü; ützi / etxenguer / ibilten \& ibiltzen; gintzün / arrahaur / iruerren 'hirugarren'

Labetze (Amiküzeko ipar-erdigunea): ezarri, ingürü / nihur e, nihunkoek / hemen /II/ / etxengo lanak; etxengo jatekoa; gañan / erremorkain gañean sar; ikhas liote / atzeman düü jende hunik; fuina ta horiek, ollo ta jaten dütenik frango etxetan; nun e saltzen ahal bitüte; plazatzeko jenden \& eosteko oihenain'; eztakiat Itsasuko zenez / abooxeak, lanean eontsi, galdua 'galdoa, eskaera', güniak, üüikatzen 'igurikatzen' / bierren 'bigarren', iruerren \& hiruerren, hogei, kuntre, prauiak 'pobreak', xerbitxü, jelgi E ielgi, juiten

Ilharre (Amiküzeko ipar-erdigunea): haragi', ingürü / ** gei 'nahi' / ederrena, eritasünetan /III lübüü; azerü \& axerü, barrükü; zari 'ezarri'; aizo / arrasartzen, haooxia, iüükatü 'igurikatu' / aatze 'ahantzi', hautse 'hautsi', ho(g)ei; bierren

Gamue (Amiküzeko ipar-ekialdea): //// bürü / bañotek / urez betha / abooxietan, atsarrian / hiugerrena

Arboti (Amiküzeko ipar-ekialdea): iortzen, zartzen /II/ ülüntzetan; muzten 'mozten'; güre \& güe; bürü; axerüka; ezari / etxengo lürretan; etxen / etzatazü üdüri / haoxiak 'haboroxeak'

Zohota (Amiküzeko ipar-ekialdea): ederra //// hanxe, horxe; xerbüxü 'zerbitzu'; ezkundu E ezkunt eta; aizoak; nur 'nor'; ezari 'ezarri' \& ezaiko 'ezarriko' / etxengoa; zakü at hire ta zakü at etxetierrein; olaxet / egünaz bil / uai libertitzez ai zizte lanian; hoitan ootan bauk biziki jende lanian ai denik; erran zikan bazela zeit juten etzenik / aidürü, aitañi \& amañi, arrajin, eli bat, oskiak / aatze 'ahaztu', hogeieko, ene kuntre, ontarzüna

Arberatze (Amiküzeko erdigune-ekialdea): apezeikin / ibiltzen / aitatxik, ibiakoitza 'larunbata' / ano 'ardo', auzo, behor, berdin, eder, gasna, haitz 'haritz', hemen, idüritzen, libürü, paatu 'ordaindu' IIII etxengo; behiaiki / arrahaur, askazi, ekhi, eontsi, hatsarria / aizo, haboro, kuntre, nuiz; eritarsüna

Laphizketa (Amiküzeko erdigune-ekialdea) ${ }^{10}$ : muthil; jakin / elgarrekin; nihuk e / izartzia, igort-

8. Genitiboan jokatzen den osagarri zuzena extraposizioan kokaturik ageri da bi adibideotan.

9. Hitza Zuberoan nagusiki $h$ - gabea den aldetik. Oihergin, esaterako, agia bildu dugu, baina Pagolan hagía.

10. Laphizketan bildu dugu goai bezanbat konparazioko egitura, baina EHHA-n Zuberoan eta Amiküzen bezainbeste nagusitzen da. Martin Maister zuberotarraren lanean (1757), bezanbat eta bezañ beste, bi erak ageri dira. 
zeko; ibili //I/ üdüri \& üdüipenak, ülüntzetan; horxe; ezari 'ezarri' / ezarten, igorteko; izan zatazü / ekhia, gei 'nahi' / bigerren, -tarzün

Domintxaine (Zuberoako ipar-mendebala): gauza, gau; abendu, jende, heldü / nihukek 'nehork', nihun e / düte /II/ lübüria, üdüi 'iduri' / habooxiak / hamabigerren, heen 'hemen', kuntre

Etxarri (Zuberoako ipar-mendebala) ${ }^{11}$ : yeraikitzen ${ }^{12}$; auzoak, gauza; gure, gero; alde, iandian 'igandean' / dute \& tuzte; ibiltzen \& iiltzen, itzultzea / emen 'hemen' /III []uitean 'joaitean', iante 'igande'; beriz 'berriz', heriak 'herriak', eran 'erran', haurik 'haurrik' / emenko \& etxengoek; etxen baita etxean ere / hogei; goxotarzün

\section{Hondarreko lerroak}

Hizkuntzaren aldakortasunaz oro har eta gertakari honek Amiküzen eta Zuberoako ipar-mendebalean duen agerpenaz mintzatzea izan da artikulu honen helburua: datu-bildumaren baitako aldakortasuna, aldakortasun fonologikoa, aldakortasun grafikoa, idazki zaharretan ageri den aldakortasun geolinguistikoa eta mendebaletik ekialderat hamabost herritan gaindi ageri den hizkuntzacontinuum-a aurkeztu ditugu hona. Ez dugu eskualde honetako mintzoaz osotasuneko ikuspegirik ekarri: emaitza gehiago biltzean eta beren izaera dialektologiko eta kronologikoa xehekiago aztertzean etorriko dira interpretazio sakonagoak.

Amiküzek eta Zuberoako ipar-mendebalak historikoki gizarteko hartu-eman sendoa eduki dute eta horrek bi alderdietako mintzoen arteko antzekotasun edo erlazio maila zenbait eragin du; bi ibarretako euskarak salatzen digu hori. Esaterako, bait > bit soiltzea, Baigorrialdean salbu Baxenabarre gehienean eta Lapurdiko ekialdean gertatu da; Amiküzen ere bit entzuten da, baina Xiberuan beit baliatzen da; Ainharbetik eskuin beit ageri da Zuberoan nagusi, baina mugaren inguruan, Domintxaine, Lohitzüne edo Oihergi herri xiberutarretan bit bildu dugu guk.

Amiküzen izan ezik, Baxenabarren ez dago beste mintzorik Zuberoako euskararen halako kutsua duenik, ez Garazin ezta Oztibarren ere; amiküztarrek berek dioskute —Laphizketako lekuko batek, hain zuzen ere-, Baionan xiberutartzat dituztela, xiberutarrek amiküztarrak manextzat jotzen badituzte ere. Amiküzeren eta Zuberoaren arteko hartu-eman sozio-geografikoa naturalki gauzatu da historian zehar eta hainbat hizkuntza-ezaugarri bi mintzoetan berdinak izatea eragin du. Donapaleu bilgune garrantzizkoa izan da zerbitzuen eta ekonomiaren alderditik eta egun ere erakargune izaten jarraitzen du, guztiz hiri erdalduna bilakaturik badago ere.

Zernahi ere den, Amiküzek hartu-eman sendoa eduki du Baxenabarrerekin, Zuberoarekin baino areago segurki, eta orain ere halaxe da, mintzoak berak ezagun du hori; egun amiküztarrek hizkuntza-eragin gehiago biltzen dute ezkerreko eta peko alderditik, Nafarroa Behereko erdigune eta hegotik, Xiberutik baino, hain baita larria mintzo zuberotarraren egoera; bertan ere egiten ez den üskaa-k nekez izan dezake eraginik Zuberoako mugetarik kanpo. Bestalde, egun oroz manexetik nahiz xiberutarretik ematen duten euskal irratiek mugaren inguruko eskualde honetako mintzoan ukan ahal izan duten eragina neurtzeko ez dugu inolako tresnarik.

11. Ez dakigu Etxarriko emaitza hauek zenbateraino ordezkatzen duten leialtasunez herriko eguneroko mintzo arrunta.

12. Euskalerriko Atlas Etnolinguistiko-an sabaiaurreko ozena ageri da Etxarrin; Marianne Luye lekukoak žente eta žiten dakartza 1980ko etnotestuan; guk ere bildu dugu sabaiaurreko ozena Etxarrin, baina adibide guztietan ez. 
Saioaren hasieran adierazi dugu muga dialektalaren inguruko hiztunek halako mintzo "diffuse" eta ñabarra eduki ohi dutela, hizkuntzaren aldetik enfoke bat baino gehiago ukan dezaketela, beren bizian ezagutu duten ohiko hizkuntza-merkatuan alderdi bateko eta besteko hiztunekin jardun beharra izan dutela, beren ohiko edo eguneroko gizarte-sarean, gutienez bi eremu lektaletako ohituren aitzinean gertatzea egokitu zaiela.

Mintzalagunari egokitu beharra arau unibertsaltzat jotzen da hizkuntzalaritzan eta soziolinguistikan: badakigu muga dialektalaren inguruko hiztunek joera dutela muga lektalaz bestaldekotik ere emateko, bereziki beren herriko hiztunen aitzinean ez daudenean, mintzalaguna muga lektalaz bestaldeko pertsona bat denean ala lagun ezezagun bat denean. Hiztun hauen segurtasun dialektal edo linguistikoa ez da ondarrutar batek edo zaldibiar batek eduki dezakeen bezainbatekoa. Gai hau guztiz aintzat hartzekoa da Etxarrin, Arüen, Olhaibin, Sarrikotapean, Lohitzünen edo Oihergin eta gehienbat Pagolan; herri horietako hizkuntza-egoera aztertzen ari denean, behatzailearen paradoxa gainditu gogo luke ikertzaileak bere nahi eta ezinean.

Azken buruan, dialektologiaren alorrean ageri diren gertakari konplexuek, aldakortasunak hango eta hemengo hizkuntzalaritzan ezinbestean eragiten dituen galderen multzoa elikatzen dute; lerrootan aurkeztu den ikuspegi teorikoak eta ekarri diren euskal adibideek auzi hau kokatzen eta argitzen lagundu baldin badute, saio hau idazten hastean genuen helburua bete dela esan dezakegu.

\section{Bibliografia}

Agirre, P., 2001, "Belapeireren grafiak" ASJU 35/1, 299-361.

Aurrekoetxea, G. \& X. Videgain, 2004, Haur prodigoaren parabola Ipar Euskal Herriko 150 bertsiotan, ASJU-ren gehigarriak 49, EHU, Bilbo.

Bárczi, G., 1963, "Les recherches dialectologiques en Hongrie”, Orbis 12, 141-156.

Bonaparte, L.L., 1869, Le verbe basque en tableaux, Londres. Ikus orain Euskaltzaindiaren 1991ko Opera omnia vasconice I, Bilbo.

Bouvier, J. C., 1998, "Tavola rotonda", in G. Ruffino (arg.), Atti del XXI Congresso Internazionale di Linguistica e Filologia Romanza, Max Niemeyer Verlag, Tübingen, 777-785.

Camino, I., 2004, "Nafarroa Behereko euskara", FLV 97, 445-486.

—. 2008, "Nafarroa Behereko euskara zaharra", ASJU 42/1, 101-169 or.

—. 2009, "Mugako hiztun eta aldaerak ipar-mendebaleko Zuberoan", FLV 111, 153-218.

Dees, A., 1988, "Propositions for the study of Old French and its dialects", in J. Fisiak (arg.), Historical Dialectology. Regional and Social, Mouton de Gruyter, Berlin-New York-Amsterdam, 139-148.

—. 1989, "La reconstruction de l'ancien français parlé", in M. E. H. Schouten \& P. Th. van Reenen (arg.), New Methods in Dialectology, Foris, Dordrecht - Holland/Providence RI - U.S.A, 125-133.

Etxebarria, J. M., 1994, "Las grabaciones de Viena en euskera. Bajo navarro occidental y bajo navarro oriental", Mundaiz 47, 45-75.

Fischer, J. L., 1958, "Social influences on the choice of a linguistic variant", Word 14, 47-56.

Hualde, J. I., 1997, Euskararen azentuerak, ASJU-ren gehigarriak 42, Gipuzkoako Foru Aldundia \& Euskal Herriko Unibertsitatea, Donostia \& Bilbo.

Irizar, P., 2002a, Morfología del verbo auxiliar bajo navarro oriental, 2. liburukia, Euskaltzaindia, Bilbo. 
—. 2002b, Morfología del verbo auxiliar suletino, Euskaltzaindia, Bilbo.

Isebaert, L., 1977, H. Haarmann. 1977. Grundzüge der Sprachtypologie. Methodik, Empirie und Systematic der Sprachen Europas lanaren aipamena, Orbis 26, 180-181.

Kac, M. B., 1996, "Foreword. Present at the creation: a reminiscence of the summer of '63", in G. R. Guy, C. Feagin, D. Schiffrin \& J. Baugh (arg.), Towards a social science of language. Papers in honor of William Labov, volume I, Variation and change in language and society, Benjamins, Amsterdam-Philadelphia, xv-xviii.

Kroch, A. S., 1986 [1976], "Toward a theory of social dialect variation", in H. B. Allen \& M. D. Linn (arg.), Dialect and Language Variation, Academic Press, INC., San Diego, 344-366.

Lafon, R., 1962, "Sur la voyelle ü en basque", BSL 57, 83-102.

Le Page, R. B., 1980, "Projection, focusing, diffusion, or steps towards a sociolinguistic theory of language", York Papers in Linguistics 9, 9-33.

Linn, M. D., 1983, "Informant selection in Dialectology", American Speech 58, 225-243.

Malkiel, Y., 1984, "Revisionist dialectology and mainstream linguistics", Language in Society 13, 29-66.

Milroy, L., 1980, Language and social networks, Blackwell, Oxford.

— \& S. Margrain, 1980, "Vernacular language loyalty and social network", Language in Society 9, 43-70.

Orpustan, J.-B., 2005, "Sermons basques du XVIII siècle en Pays de Cize. Euskal-pheredikuak Garazin XVIII-garren mendean (Archives de la maison Iriberria de Bascassan)", Lapurdum 10, 169-232.

Paddock, H., 1988, "The actuation problem for gender change in Wessex versus Newfoundland", in J. Fisiak (arg.), Historical Dialectology. Regional and Social, Mouton de Gruyter, Berlin-New York-Amsterdam, 377-395.

Rona, J. P., 1976, "The social dimension of dialectology", International Journal of the Sociology of Language 9, 7-22.

Sankoff, D. \& S. Laberge, 1978, "The linguistic market and the statistical explanation of variability", in D. Sankoff (arg.), Linguistic variation. Models and methods, Academic Press, INC, New York, 239-250.

Sčur, G.S. 1967, "A comparative-historical study of cognate languages and dialectology", Orbis 16, $5-22$.

Trudgill, P., 1986, Dialects in contact, Blackwell, Oxford.

Villena, J. A., 1990, "Las consecuencias lingüísticas de ser una mujer. Notas para la intervención teórica en el campo de la conexión entre la lengua y el sexo", in La mujer en el mundo contemporáneo. Realidad y perspectivas, Diputación provincial, Malaga, 151-191.

Weinreich, U., 1954, "Is a structural dialectology possible?", Word 10, 388-400.

Weinreich, U., W. Labov \& M. I. Herzog, 1975 [1968], "Empirical foundations for a theory of language change", in W. P. Lehmann \& Y. Malkiel (arg.), Directions for historical linguistics, University of Texas Press, Austin \& Londres, 95-195.

Zamora, F. J., 1986, "Algunos aspectos psicosociolingüísticos y contextuales de la variación lingüística”, Anuario de Lingüística Hispánica 2, 277-323.

Zawadowsky, L., 1961, "Les dialectes d'origine différente en contact", Orbis 10, 293-307. 